\title{
Peningkatan Tanggung Jawab dan Keterampilan Proses IPA Melalui Model CTL Berbasis Daring Siswa Kelas IV SDN Cangkringan 1
}

\author{
Yohana Fransiska Lintang Natalia ${ }^{* 1}$, Andri Anugrahana ${ }^{2}$, Ehsan Zaini ${ }^{3}$ \\ ${ }^{1,2,3}$ Program Pendidikan Profesi Guru Sekolah Dasar, \\ Universitas Sanata Dharma Yogyakarta, Indonesia. \\ Email: 1'yohananatalia605@gmail.com, ${ }^{2}$ andrianugrahana@gmail.com, 3ihsanzaini@gmail.com
}

\begin{abstract}
Abstrak
Latar belakang penelitian ini adalah untuk mengetahui peningkatan tanggung jawab dan keterampilan proses IPA melalui model pembelajaran CTL berbasis pembelajaran daring pada siswa kelas IV SDN Cangkringan 1. Penelitian ini merupakan Penelitian Tindakan Kelas (PTK). Penelitian ini dilaksanakan dengan dua siklus. Subyek dalam penelitian ini adalah seluruh siswa kelas IV SDN Cangkringan 1 yang berjumlah 9 siswa. Teknik pengumpulan data menggunakan wawancara dan observasi. Validitas data yang digunakan adalah expert judgment. Hasil penelitian ini menunjukkan bahwa penerapan model pembelajaran CTL berbasis pembelajaran daring dapat meningkatkan tanggung jawab dan keterampilan proses IPA siswa kelas IV SDN Cangkringan 1. Perolehan skor rerata tanggung jawab siswa pada siklus I adalah 64 dan siklus II rerata meningkat menjadi 74,07. Rerata tanggung jawab termasuk kategori bertanggung jawab. Perolehan skor rerata keterampilan proses IPA pada siklus I adalah 56,67 dan rerata meningkat menjadi 71,11 dan termasuk kategori baik. Penelitian secara daring ini menggunakan aplikasi Whatsapp Group dan Google meet.
\end{abstract}

Kata kunci: CTL, keterampilan proses IPA, pembelajaran daring, tanggung jawab.

\section{Increasing Responsibility And Science Process Skills Through CTL Model Based On Online For Class IV Students Of SDN Cangkringan 1}

\begin{abstract}
The background of this research is to know the increase of responsibility and science process skills through online learning based on the Contextual Teaching Learning model for 4th-grade students of SDN Cangkringan 1. This research is Classroom Action Research (CAR). This research is done with two cycles. The subjects in this study were all fourth-grade students at SDN Cangkringan I in total nine students. Data collection techniques were using interviews and observation. The validity of the data that used in this research is expert judgment. The results of this study indicate that the application of the CTL learning model based on online learning can increase the responsibility and science process skills of fourth-grade students at SDN Cangkringan I. The average score of student responsibility in the first cycle is 64 and the average second cycle increases to 74.07. The average responsibility belongs to the responsible category. The average score of science process skills in the first cycle was 56.67 and the average increased to 71.11 and included in the good category. This research use application Whatsapp Group and Google meet.
\end{abstract}

Keywords: CTL, online learning, responsibility, science process skills.

\section{PENDAhuluan}

Dalam pasal 3 Bab II Undang-Undang (UU) Pendidikan nomor 20 Tahun 2003 dinyatakan bahwa Pendidikan Nasional berfungsi mengembangkan kemampuan dan membentuk watak serta peradaban bangsa yang bermartabat dalam rangka mencerdaskan kehidupan bangsa, tujuannya untuk berkembangnya potensi siswa agar menjadi manusia yang beriman dan bertakwa kepada Tuhan Yang Maha Esa, berakhlak mulia, sehat, berilmu, cakap, kreatif, mandiri, menjadi warga negara yang demokratis dan bertanggung jawab [1].

Sekolah (SD) merupakan salah satu pendidikan formal yang memiliki peran besar untuk membentuk karakter dan keterampilan siswa. Salah satu karakter yang perlu ditanamankan sejak SD yaitu tanggung jawab. Tanggung jawab merupakan sikap dan perilaku siswa untuk melaksanakan tugas dan kewajibannya, yang seharusnya dilakukan terhadap diri sendiri, masyarakat, lingkungan, negara, dan Tuhan Yang Maha Esa [2]. 
Indikator yang akan digunakan dalam penelitian ini adalah a) mempersiapkan diri sebelum memulai pembelajaran daring selama pandemi covid-19, b) mengumpulkan tugas tepat waktu, c) Menyelesaikan tugas sesuai petunjuk dan pembagian tugas, dan d) membersihkan perlengkapan yang sudah selesai digunakan.

Keterampilan proses IPA menurut Depdiknas adalah keterampilan yang digunakan siswa untuk menyelidiki dunia sekitar mereka serta untuk membangun konsep suatu ilmu pengetahuan [3]. Keterampilan proses terdiri dari beberapa aspek. Adapun indikator keterampilan proses terdiri dari beberapa pendapat sebagai berikut:

Tabel 1. Indikator keterampilan proses pendapat ahli

\begin{tabular}{lll}
\hline Hosnan, 2014:370 [4] & Kemedikbud, 2013: 215 [5] & Patta, 2006: 24 [6] \\
\hline 1. Mengamati & 1. Pengamatan & 1. Observing \\
2. Mengklasifikasi & 2. Pengukuran & 2. Planning, \\
3. Menafsirkan & 3. Menyimpulkan & 3. Hypothesizing, \\
4. Meramalkan & 4. Meramalkan & 4. Interpreting, \\
5. Menerapkan & 5. Menggolongkan & 5. Communicating \\
6. Merencanakan penelitian & 6. Mengkomunikasikan & \\
7. Mengkomunikasikan & & \\
\hline
\end{tabular}

Berdasarkan pendapat para ahli tersebut, keterampilan proses yang akan dikembangkan dalam penelitian ini adalah keterampilan observasi, keterampilan melakukan percobaan, keterampilan menyimpulkan, dan keterampilan komunikasi. Hal ini disebabkan karena keempat keterampilan proses tersebut merangkum dari para pendapat para ahli.

Saat ini, di Indonesia sedang terjadi pandemi covid-19. Pemerintah provinsi dan pemerintah daerah membuat kebijakan untuk mengganti pembelajaran tatap muka dengan pembelajaran dalam jaringan (daring) [7]. Salah satu sekolah yang menetapkan sistem pembelajaran daring pada masa pandemi covid-19 ini adalah SDN Cangkringan 1 Yogyakarta. Berdasarkan hasil observasi dan wawancara guru kelas, peneliti mendapatkan data bahwa siswa kelas IV memiliki sikap kurang bertanggung jawab. Peneliti mendapatkan hasil dari 10 siswa di kelas, terdapat 5 atau $50 \%$ siswa yang pernah terlambat dalam pengumpulan tugas. Peneliti juga menemukan bahwa pelaksanaan kegiatan pembelajaran daring kurang mengembangkan keterampilan proses.

Pemasalahan yang ada di kelas IV SDN Cangkringan 1 perlu diatasi. Tujuan penelitian ini adalah untuk meningkatkan sikap tanggung jawab dan keterampilan proses IPA siswa, perlu diterapkan model pembelajaran yang sesuai. Salah satu model pembelajaran yang dapat digunakan adalah model pembelajaran CTL (Contextual Teaching and Learning) berbasis pembelajaran daring. Model pembelajaran CTL merupakan suatu proses pembelajaran yang holistik dan bertujuan memotivasi siswa untuk memahami makna materi pembelajaran yang dipelajarinya dengan mengaitkan materi tersebut dengan konteks kehidupan sehari-hari sehingga siswa memiliki pengetahuan atau keterampilan yang secara fleksibel dapat diterapkan dari suatu permasalahan ke permasalahan lainnya. Model pembelajaran CTL terdiri dari 7 langkah yaitu: 1) konstruktivisme (membangun), 2) questioning 3) inkuiri, 4) masyarakat belajar, 5) pemodelan, 6) refleksi, dan 7) penilaian yang sebenarnya [8].

Berdasarkan permasalahan yang telah dipaparkan, peneliti tertarik untuk melakukan penelitian tindakan kelas (PTK) mengenai "Peningkatan Tanggung Jawab dan Keterampilan Proses IPA Melalui Model Pembelajaran CTL Berbasis Pembelajaran Daring Siswa Kelas IV SDN Cangkringan 1". Tema yang digunakan adalah tema 8 (Daerah Tempat Tinggalku) dengan konsentrasi muatan pelajaran IPA khususnya materi gaya dan gerak.

\section{METODE PENELITIAN}

Jenis penelitian yang digunakan adalah penelitian tindakan kelas. Penelitian tindakan kelas merupakan suatu pencermatan terhadap kegiatan belajar berupa sebuah tindakan, yang sengaja dimunculkan dan terjadi dalam sebuah kelas secara bersama [9]. Penelitian ini menggunakan model penelitian menurut Kemmis dan Taggart. Berikut ini merupakan langkah-langkah PTK menurut Kemmis \& McTaggart [10].

Penelitian dilaksanakan di SDN Cangkringan 1 yang terletak di Brongkol, Argo Mulyo, Kecamatan Cangkringan, Kabupaten Sleman, Daerah Istimewa Yogyakarta. Penelitian di SDN Cangkringan 1dilaksanakan pada semester genap tahun ajaran 2020/2021. Penelitian dilakukan pada bulan Februari - Maret 2021. Subyek penelitian ini adalah siswa kelas IV SDN Cangkringan 1 tahun pelajaran 2020/2021 yang berjumlah 9 siswa yang terdiri dari 8 siswa laki-laki dan 1 siswa perempuan.

Penelitian mengumpulkan data penelitian menggunakan beberapa teknik, yaitu (1) wawancara dan (2) observasi. Penelitian ini mengumpulkan data dengan melakukan wawancara terstruktur kepada guru kelas IV tentang proses pembelajaran yang berlangsung. Peneliti melakukan wawancara online. Kegiatan wawancara ini digunakan untuk menentukan masalah pada saat pra-penelitian. Observasi dalam penelitian ini bertujuan untuk (1) mengetahui kondisi awal siswa, (2) mengamati tanggung jawab dan keterampilan proses siswa selama proses pembelajaran. 


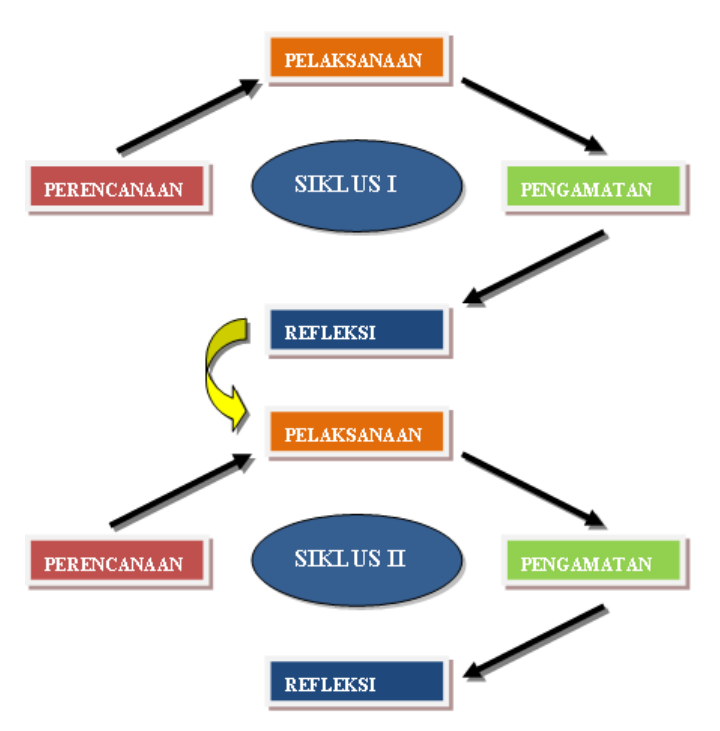

Gambar 1. Desain PTK menurut Kemmis \& Mc Taggart

Instrumen penelitian yang digunakan berupa pedoman wawancara dan lembar observasi. Instrumen pedoman wawancara digunakan untuk menggali informasi dari guru terkait proses pembelajaran dan permasalahan yang ada di kelas. Lembar observasi bertujuan untuk melihat tanggung jawab dan keterampilan proses IPA peserta didik dalam mengerjakan tugas yang diberikan selama proses pembelajaran daring. Lembar observasi disusun berdasarkan indikator yang telah ditentukan oleh peneliti.

Teknik analisis data yang digunakan adalah teknik analisis data kualitatif. Berikut ini penjelasan analisis data dalam penelitian ini.

1) Menghitung nilai keterampilan proses IPA setiap peserta didik dengan rumus sebagai berikut.

$$
\text { Keterampilan Proses IPA }=\frac{\text { Jumlah Skor Keterampilan Proses IPA }}{\text { Jumlah Skor Maksimal }} \times 100
$$

2) Menghitung nilai keterampilan proses IPA seluruh peserta didik dengan rumus sebagai berikut.

$$
\text { Keterampilan Proses IPA }=\frac{\text { Jumlah Skor Keterampilan } \text { Proses IPA seluruh siswa }}{\text { Jumlah total siswa }} \times 100
$$

Kategori keterampilan proses IPA adalah sebagai berikut [9].

Tabel 2. Kategori keterampilan proses IPA

\begin{tabular}{ccc}
\hline Interval Nilai & Nilai Huruf & Kategori \\
\hline $80-100$ & A & Sangat Baik \\
$60-79$ & B & Baik \\
$40-59$ & C & Cukup Baik \\
$20-39$ & D & Kurang Baik \\
Di bawah 20 & E & Sangat Kurang Baik \\
\hline
\end{tabular}

3) Menghitung nilai tanggung jawab setiap peserta didik dengan rumus

$$
\text { Nilai Tanggung Jawab }=\frac{\text { Jumlah Skor Tanggung Jawab setiap siswa }}{\text { Jumlah Skor Maksimal }} \times 100
$$

4) Menghitung nilai tanggung jawab seluruh peserta didik dengan rumus sebagai berikut.

$$
\text { Nilai Rata-Rata }=\frac{\text { Jumlah Skor Tanggung Jawab seluruh siswa }}{\text { Jumlah total siswa }} \times 100
$$


Kategori tanggung jawab adalah sebagai berikut [11]

Tabel 3. Kategori tanggung jawab

\begin{tabular}{ccc}
\hline Interval Nilai & Nilai Huruf & Kategori \\
\hline $80-100$ & $\mathrm{~A}$ & Sangat Bertanggungjawab \\
$70-79$ & $\mathrm{~B}$ & Bertanggungjawab \\
$60-69$ & $\mathrm{C}$ & Cukup Bertanggungjawab \\
$50-59$ & $\mathrm{D}$ & Kurang Bertanggungjawab \\
Di bawah 50 & $\mathrm{E}$ & Tidak Bertanggungjawab \\
\hline
\end{tabular}

\section{HASIL DAN PEMBAHASAN}

Pada bagian ini akan mendeskripsikikan hasil penelitian dan pembahasan tentang keterampilan proses IPA dan tanggung jawab setelah pelaksaan pembelajaran menggunakan model pembelajaran CTL berbasil daring. Penelitian Tindakan Kelas terdiri dari dua siklus. Setiap siklus terdiri dari 2 pertemuan.

Hasil penelitian tanggung jawab siswa kelas IV SDN Cangkringan 1 diperoleh melalui lembar observasi siswa. Hasil pengamatan dapat disimpulkan bahwa tanggung jawab siswa mengalami peningkatan di setiap siklusnya. Berikut merupakan hasil penelitian variabel tanggung jawab.

Tabel 4. Hasil penelitian variabel tanggung jawab setiap siklus

\begin{tabular}{lllcc}
\hline \multicolumn{2}{c}{ Indikator } & $\begin{array}{c}\text { Kondisi } \\
\text { Awal }\end{array}$ & $\begin{array}{c}\text { Siklus I } \\
\text { Siklus } \\
\text { II }\end{array}$ \\
\hline A & $\begin{array}{l}\text { Mempersiapkan diri sebelum memulai } \\
\text { selama pandemi covid-19 }\end{array}$ & 44,44 & 55,56 & 74,07 \\
B & Mengumpulkan tugas tepat waktu & 61,11 & 69,44 & 72,22 \\
C & Menyelesaikan tugas sesuai petunjuk dan pembagian tugas & 61,11 & 72,22 & 88,89 \\
D & Membersihkan perlengkapan yang sudah selesai digunakan & 55,56 & 59,25 & 66,67 \\
\hline
\end{tabular}

Indikator tanggung jawab mengalami peningkatan mulai dari kondisi awal, siklus I, hingga siklus II. Kondisi awal tanggung jawab yang ditunjukkan pada indikator A dan D sangat perlu ditingkatkan. Setelah dilakukan siklus I, setiap indikator mengalami peningkatan dengan indikator C yang tertinggi mencapai 72,22. Meskipun mengalami peningkatan, namun indikator A dan $\mathrm{C}$ masih perlu ditingkatkan kembali. Pada akhir siklus II, diperoleh data rerata indikator A 74,07. Rerata yang dicapai siswa pada indikator B 72,22 dan indikator C 88,89 . Kemudian rerata pada indikator D yaitu 66,67 . Hal ini menunjukkan bahwa tanggung jawab mengalami peningkatan pada setiap indikator.

Berdasarkan hasil yang diperoleh tanggung jawab siswa dalam mengikuti pembelajaran mengalami peningkatan di setiap siklusnya. Pada kondisi awal rerata yang diperoleh adalah 55. Rerata tanggung jawab pada siklus I adalah 64. Hasil pada rerata siklus II juga menununjukkan peningkatan dengan rerata 74,07. Berikut merupakan grafik peningkatan rerata tanggung jawab pada setiap siklusnya.

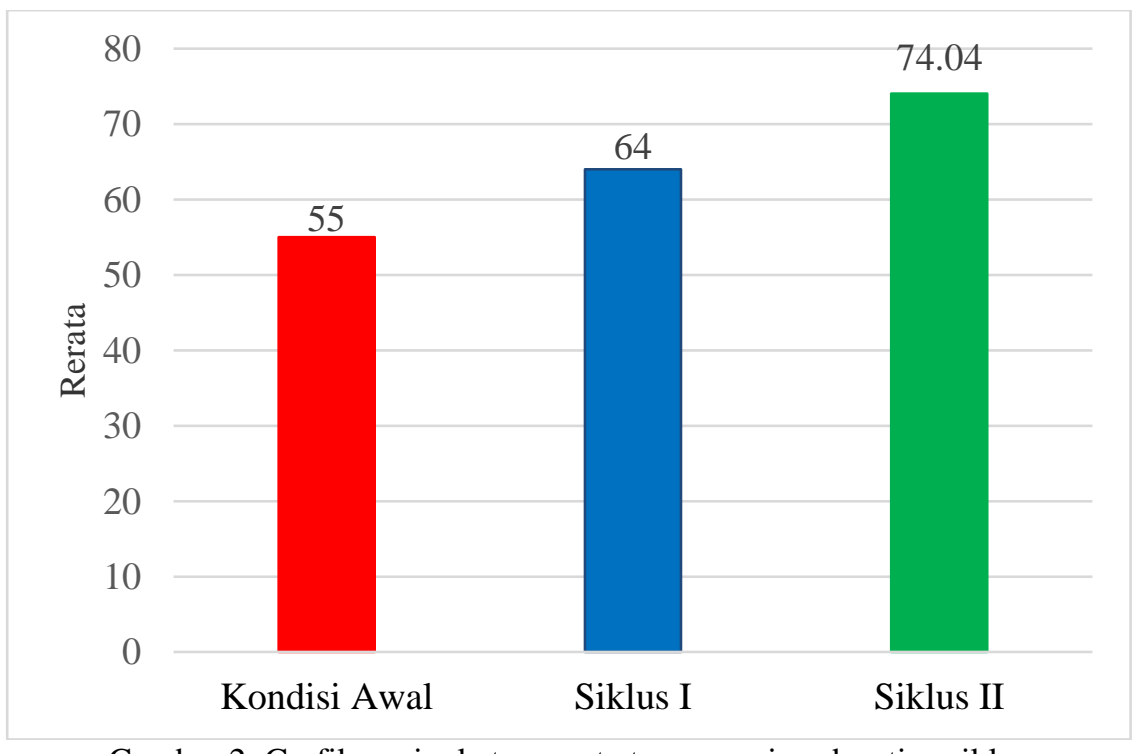

Gambar 2. Grafik peningkatan rerata tanggung jawab setiap siklus 
Peningkatan keterampilan proses IPA siswa diperoleh melalui pengamatan dengan lembar observasi. Varibel keterampilan IPA pada penelitian ini mengalami peningkatan pada setiap siklusnya. Berikut merupakan hasil peningkatan variabel keterampilan proses IPA.

Tabel 5 Hasil penelitian variabel keterampilan proses IPA setiap siklus

\begin{tabular}{|c|c|c|c|c|}
\hline & Indikator & $\begin{array}{c}\text { Kondisi } \\
\text { Awal }\end{array}$ & Siklus I & $\begin{array}{c}\text { Siklus } \\
\text { II }\end{array}$ \\
\hline $\mathrm{A}$ & Keterampilan observasi & 44,44 & 55,56 & 77,78 \\
\hline B & Keterampilan melakukan percobaan & 50 & 63,89 & 72,22 \\
\hline $\mathrm{C}$ & Keterampilan menyimpulkan & 50 & 61,11 & 72,22 \\
\hline $\mathrm{D}$ & Keterampilan komunikasi & 33,33 & 44,44 & 66,67 \\
\hline
\end{tabular}

Kondisi awal keterampilan proses IPA yang ditunjukkan pada indikator A dan D sangat perlu ditingkatkan. Setelah dilakukan siklus I, setiap indikator mengalami peningkatan dengan indikator B yang tertinggi mencapai 63,89. Meskipun mengalami peningkatan, namun indikator A, B, C dan D masih perlu ditingkatkan kembali. Pada akhir siklus II, diperoleh data rerata indikator A 77,78. Rerata yang dicapai siswa pada indikator B 72,22 dan indikator C 72,22. Kemudian rerata pada indikator D yaitu 66,67.

Pada kondisi awal rerata yang diperoleh adalah 44,44. Rerata keterampilan proses IPA pada siklus I adalah 56,67. Hasil pada rerata siklus II juga menununjukkan peningkatan dengan rerata 71,11 . Hal ini menunjukkan bahwa target keberhasilan tanggung jawab dapat tercapai. Berikut merupakan grafik peningkatan rerata keterampilan proses IPA setiap siklusnya.

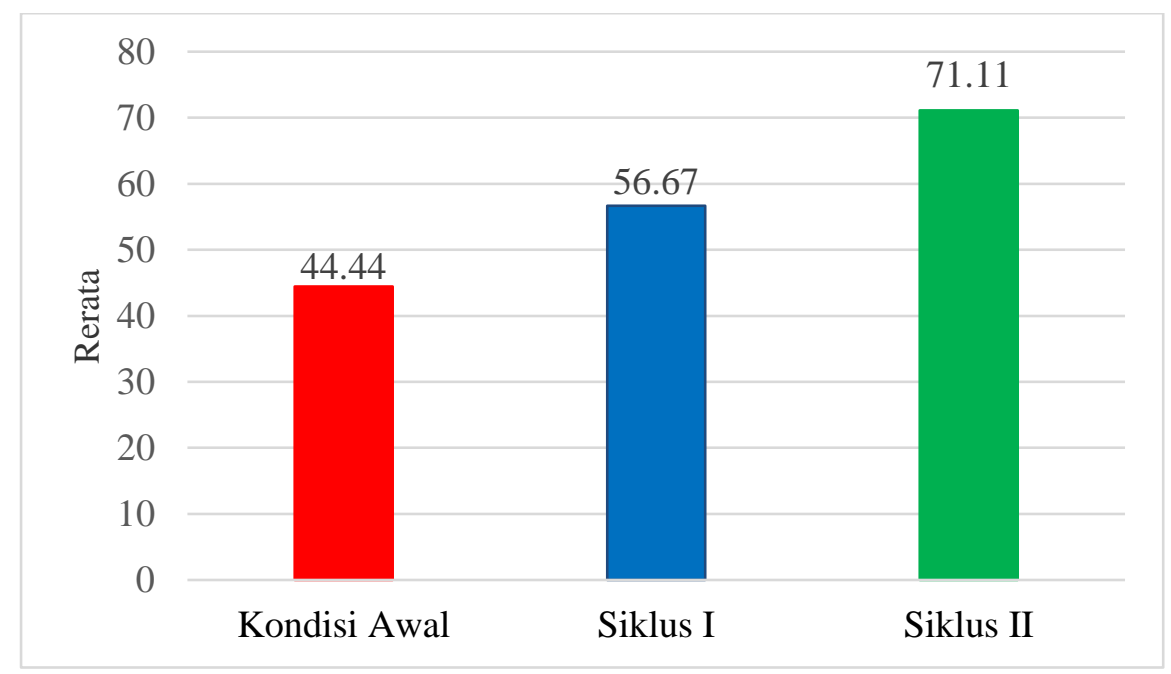

Gambar 3. grafik peningkatan rerata keterampilan proses IPA setiap siklus

\section{KESIMPULAN}

Langkah-langkah penerapan model pembelajaran CTL secara daring untuk meningkatkan tanggung jawab dan keterampilan proses IPA materi gaya dan gerak untuk siswa kelas IV SDN Cangkringan 1 adalah sebagai berikut: konstruktivisme (Constructivism), bertanya (Questioning), menemukan (Inquiri), masyarakat belajar (Learning Community), permodelan (Modeling), refleksi dan penilaian sebenarnya (Authentic Assessment).

Penerapan model pembelajaran CTL berbasis daring dapat meningkatkan tanggung jawab siswa pada materi gaya dan gerak untuk siswa kelas IV SDN Cangkringan 1 Yogyakarta. Hal ini ditunjukkan dengan tercapainya indikator tanggung jawab. Peningkatan terjadi di setiap siklus. Kondisi awal rerata yang diperoleh adalah 55. Pada siklus I rerata meningkat menjadi 64 dan rerata meningkat menjadi 74,07.

Penerapan model pembelajaran CTL berbasis daring dapat meningkatkan keterampilan proses IPA siswa pada materi gaya dan gerak untuk siswa kelas IV SDN Cangkringan 1 Yogyakarta. Hal ini ditunjukkan dengan tercapainya indikator keterampilan proses IPA. Peningkatan terjadi di setiap siklus. Kondisi awal rerata yang diperoleh adalah 44,44. Pada siklus I rerata meningkat menjadi 56,67 dan rerata meningkat menjadi 71,11. 


\section{DAFTAR PUSTAKA}

[1] Depdiknas, Undang-undang RI No.20 tahun 2003: Tentang sistem Pendidikan nasional, Jakarta: Depdiknas, 2003.

[2] Kemendikbud, Panduan Penilaian Untuk Sekolah Dasar (SD). Jakarta: Kemendikbud, 2016,.

[3] I. Muna, . Model Pembelajaran POE (Predict-Observe-Explain) dalam meningkatkan pemahaman konsep dan keterampilan proses IPA. Jurnal Studi Agama Vol 5 Nomor 1, 2017.

[4] Hosnan, Pendekatan Saintifik dan Kontekstual dalam Pembelajaran Abad 21 Kunci Sukses Implementasi Kurikulum 2013. Bogor: Penerbit Ghalia Indonesia, 2014.

[5] Kemendikbud, Materi Pelatihan Guru Implementasi Kurikulum 2013 SMP/MTs IPA. Badan Pengembangan Sumber Daya Manusia Pendidikan dan Kebudayaan dan Penjaminan Mutu Pendidikan, Jakarta, 2013.

[6] Patta, Penilaian Keterampilan Proses dan Sikap Ilmiah dalamPembelajaran Sains. Jakarta : Depdiknas, 2006.

[7] Y. Pujilestari, Dampak Positif Pembelajaran Online Dalam Sistem Pendidikan Indonesia Pasca Pandemi Covid-19. Adalah: Buletin Hukum dan Keadilan, 4(1), 2020, 49-56.

[8] Shoimin, A, 68 Model Pembelajaran Inovatif dalam Kurikulum 2013. Yogyakarta: Arr-Ruzz Media, 2014.

[9] S. Arikunto, dkk, Penelitian Tindakan Kelas. Jakarta: PT Bumi Aksara, 2006.

[10] Sanjaya, Model-model Pembelajaran. Jakarta: Bumi Aksara, 2011.

[11] A. Haryono, Media pendidikan: pengertian, pengembangan, dan pemanfaatannya. Depok: Rajawali Pers, 2012. 